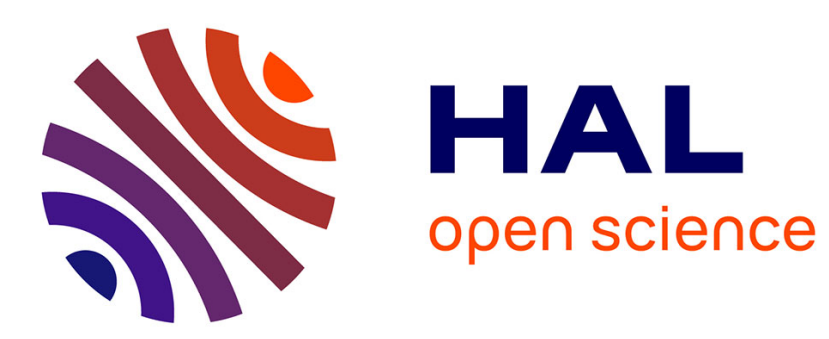

\title{
The Anthropology of Corruption
}

Davide Torsello, Bertrand Venard

\section{- To cite this version:}

Davide Torsello, Bertrand Venard. The Anthropology of Corruption. Journal of Management Inquiry, 2015, 25 (1), pp.34-54. 10.1177/1056492615579081 . hal-01238748

\section{HAL Id: hal-01238748 \\ https://hal-audencia.archives-ouvertes.fr/hal-01238748}

Submitted on 7 Dec 2015

HAL is a multi-disciplinary open access archive for the deposit and dissemination of scientific research documents, whether they are published or not. The documents may come from teaching and research institutions in France or abroad, or from public or private research centers.
L'archive ouverte pluridisciplinaire HAL, est destinée au dépôt et à la diffusion de documents scientifiques de niveau recherche, publiés ou non, émanant des établissements d'enseignement et de recherche français ou étrangers, des laboratoires publics ou privés. 
Title: The Anthropology of Corruption

\section{Drat version}

A different version of this article was published

in the Journal of Management Inquiry

To quote the original article:

Torsello, D. Venard, B. (2016). The Anthropology of Corruption, Journal of Management Inquiry, January issue, Vol 25(1), pp. 34-54.

Authors

Davide Torsello, Central European University

Frankel Leo u. 30-34,

Budapest 1023, Hungary

Bertrand Venard

Audencia. Nantes School of Management (France)

\& Wharton Business School, University of Pennsylvania, (USA)

8 , route de la Jonelière

44312 Nantes, France 


\section{Introduction}

Scholars and policy makers today recognize that corruption is increasingly pervasive in public debates on the quality and efficacy of governance. The social importance and complex nature of corruption have prompted extensive studies of the phenomenon in the social sciences. Over the last three decades, social sciences have examined a plethora of topics related to corruption, including the historical forms of corruption in the Western world (Scott, 1972; Heidenheimer, 1989), its influence on political factions and parties (Della Porta \& Vannucci 1999; Kawata, 2006), its functional role in political systems (Leff, 1964; Huntington, 1968; Montinola \& Jackman, 2002), and its nexus with democracy, civil society, and development (Bardhan, 1997; Rose-Ackerman, 1999; Doig \& Theobald, 2000; Johnston, 2005). Each discipline has its priorities in investigating corruption. For example, economists have been interested, notably in the causes of corruption and its influence on economic development (Mauro, 1995; Svenson, 1995; Aidt, 2009), while political scientists have addressed themes such as the importance of the role of political institutions and the regulation or freedom of the press in relation to corruption (Rose-Ackerman, 1999).

One of the most striking features of the "corruption boom" in the social sciences literature is the relative absence of the anthropological perspective in other sciences. Important literature reviews such as those by Jain (2001), Rose-Ackerman (2006), or Lambsdorff (2007) did not address anthropological research on corruption. For example, economists almost completely ignore the work by anthropologists on the subject. Anthropological work is rarely used by scientists in other social sciences, even though the field has developed stimulating research that offers new perspectives for exploring the phenomenon.

There are several reasons to explore corruption from an anthropological standpoint. For instance, the methodology used by anthropology to study corruption is intriguing because ethnographers use participant observation in their research. This qualitative approach offers rich and in-depth details of the phenomena.

Before analyzing the contribution of anthropology to the study of corruption, it is necessary to introduce the field. The American Anthropology Association defines the field as 
the "study of humans, past and present. To understand the full sweep and complexity of cultures across all of human history, anthropology draws and builds upon knowledge from the social and biological sciences as well as the humanities and physical sciences." The primary studies on the topic are certainly as old as humanity itself. The first known observers were travelers, priests, civil servants, and a few scholars who followed the world expansion of the colonial powers in the 19th century. They were quickly followed by many scientists who tried to consolidate the knowledge on the different societies around the world. For example, the Société d'Ethnologie de Paris was created in France in 1838, and the Ethnological Society of London followed in 1841. Early anthropologists aimed not only to understand other societies, but also to facilitate the expansion of the colonial powers. This political agenda was characteristic of early anthropologists, and continued until at least the Second World War and the Vietnam War, with intense controversies. Anthropology is now segmented in various subsections, each focusing on specific areas of research such as cultural anthropology, physical anthropology, and musical anthropology. Ethnology is a subsection of anthropology concerned with comparing human societies; it mainly rests on the results of ethnographic inquiries. Ethnography, a qualitative approach to analyzing a cultural reality (from the Greek ethnos, meaning folk or people, and grapho, to write), is a crucial research method in anthropology. An ethnographer or fieldworker carries out ethnographic research. For ethnographers, the "field" is the reality under observation. The earliest anthropologists understood the need to improve their research design. For example, the pioneer of social anthropology, Bronislaw Malinowski, is known to have brought the researcher "off the verandah," i.e. into the field, at a time when scholars mainly worked in the protected space of libraries and offices and had little contact with the "natives." Malinowski was one of the first to develop the technique of participant observation in the course of his extensive fieldwork experience among the Trobrianders (1922). Ethnography offers rich insights into corruption research; we will present its contributions later in the article.

The difference between sociology and anthropology is an old debate in the field. If we define sociology as the science of human behavior, then anthropology is a cousin of sociology (LéviStrauss, 1958/1963). Sociology is defined by the American Sociological Society as a social 
science involving the study of the social lives of people, groups, and societies. Originally, anthropology, unlike sociology, focused on societies foreign to the researcher, often smallscale cultures (this is no longer the case, however). Malinowski's study of the Trobriand islanders is one example. Sociology, in contrast aims to understand the observer's society, particularly Western societies. Today, methodology is a key difference: anthropologists mostly base their understanding on field research, which implies a long-term relationship with the reality under observation, whereas many sociologists use a variety of methods, often including quantitative empirical research. Of course, this difference is a simplification, and it is easy to find anthropologists who use quantitative analysis and sociologists who use participant observation, such as Gambetta and Heather (2005), who used an "ethnographic research method." Ethnographic methods are also applied in other social sciences such as geography, political science, and management.

Anthropological research on corruption has been carried out in recent years. Despite the abundance of theoretical and empirical works in anthropology, an in-depth analysis of this literature has yet to be carried out. This paper thus provides a critical review of the anthropological literature on corruption. In the first section, we explain the processual view of corruption. Rather than give a universal definition of corruption, anthropologists have adopted an ad-hoc perspective, taking into account the point of view of the observed. In the second part, we develop the moral view of corruption. Through many ethnographies, anthropologists have documented the socially cohesive aspect of corruption. Their empirical findings with a strong cultural relativism have led anthropologists to reject a moral judgment of corruption. After presenting some empirical findings, the next section examines the anthropological methodology. In particular, we present the richness of the qualitative method of ethnography. Our discussion on anthropological methods will lead us to examine the scope of anthropology. As we will see, anthropology traditionally starts from the analysis of a small social fact (for example, corruption) and develops toward understanding on a larger scale. The holistic analysis of corruption will be demonstrated in the last section, which concerns governance and corruption. We then highlight the crucial recurring themes in the anthropology of corruption using three angles: normative, hermeneutic, and 
transactional. After outlining the contributions of anthropology to the study of corruption, we offer some concluding remarks.

The themes under investigation in this article were selected following our literature review. Some sections are widely covered by other literature reviews in anthropology and other social sciences, such as economics. For example, the International Handbook on the Economics of Corruption covers governance in an entire chapter (Rose-Ackerman, 2006). In addition, our research team has been doing theoretical and empirical research on corruption for many years and therefore have a clear understanding of this field of research.

\section{A Processual View of Corruption}

One major contribution of anthropology is the development of an approach to the nature of knowledge that requires the researcher to critically question the concept under investigation. As we will see in this section, anthropologists are not looking to give a universal definition of corruption (Nuijten \& Anders, 2007). They see corruption as a social process involving multiple interactions within a specific socio-political environment. A social process is a pattern of joint activity that occurs regularly over time (Shibutani, 1986). On the contrary, economists have given many definitions of the concept. They commonly define corruption as "a manipulation of powers of government or sale of government property, or both, by government officials for personal use" (Shleifer \& Vishny, 1993; Jain, 1998). A similar definition has been provided by Morris, who describes corruption as "a behavior by a public official that deviates from public interest" (1991). This viewpoint is widely accepted by international institutions and is reflected in the World Bank definition of corruption as "the abuse of public office for private gain" (World Bank, 1997: 8). Corruption is therefore often defined as the misuse of public power for private benefit (Lambsdorff, 2007).

In anthropology, rather than give a universal definition, the researcher tries to understand the social reality of corruption. An ethnographer doing a survey on corruption should try to understand the socio-political context of corruption from the point of view of the "natives." Eventually, the anthropologist will realize that the above well-accepted economic definition is problematic because it is not given by the observed. For example, the 
economic definition is based on a strong private-public dichotomy. Anthropological studies have presented abundant evidence to support the argument that the opposition of public and private is context-dependent. To anthropologists, the public sphere is not easily defined, especially in comparison to the private sphere, in many of the social contexts where they undertake fieldwork.

In any research, anthropologists follow an ad-hoc approach that adopts the perspective of the "natives." The diversity of definitions of corruption justifies the adoption of such an approach. For example, the OECD (Organization for Economic Co-operation and Development, a leading international institution fighting bribery) refers to corruption as involving public servants. Inhabitants of countries such as France or India have the same commonly accepted perception of corruption as the OECD. However, Transparency International, a world-leading NGO (Non-Governmental Organization) fighting corruption, uses a much broader definition. To them, corruption does not always involve public servants, but occurs whenever there is an abuse of power. Some countries such as Germany use this broader definition. Thus, the same concept refers to very different realities at the level of various organizations and nations. This diversity is even more prominent at the individual level.

The refusal to give a universal definition derives from anthropological investigations that use an inductive analytical line of reasoning to analyze institutions, norms, and conventions at ground-level. In anthropological epistemology, a social reality might be understood only when the observer (the scientist) gives voice to the observed using the words, symbols, practices, and discourses of the observed. For example, anthropology cannot easily agree with a definition of corruption that neatly distinguishes between private and public roles, tasks, and aims. Rather than accepting this public/private dichotomy, anthropologists stress the different ways in which various actors conceive of these spheres. As a result, and unlike other disciplines, anthropology has not concerned itself expressly with proposing a typology of corruption. Instead, it has dealt with differences in studies of corruption by highlighting the processual socio-political nature of the phenomenon.

In the study of corruption, scholars such as economists have built different typologies. A very simple one distinguishes between petty and large-scale corruption based 
on the magnitude of the phenomenon (Rose-Ackerman, 2006). In a "larger" typology, Jain, an economist, defined three types of corruption: grand, bureaucratic, and legislative (1998, 2001). For anthropologists, this categorization of corruption raises a number of issues. First, using categories may imply stereotyping. When a country is said to face petty corruption, this stigmatizes the entire country by implying that the practice is a characteristic of the nation as a whole. Various stereotypes can be seen in the literature, such as "neopatrimonial states," the "belly state," "network culture," and "gift-exchange culture." Second, categories of corruption oversimplify the social reality by restricting the phenomenon to a certain number of categories. For example, to differentiate corruption, Rose-Ackerman, economist and professor of jurisprudence, analyzes only two situations, grand and petty corruption, depending mainly on volume (2006). Third, focusing on one type of corruption puts any social reality in a static state without taking into account its environment, when corruption is in fact a dynamic social reality linked to its social and political environment, which by nature changes over time.

On the one hand, ethnographers have mainly given various accounts of petty corruption that they encountered when they carried out ethnographic studies of the hidden morality of mutual ties of reciprocity, gift exchange, and interpersonal trust. In field research, the ethnographer may often observe gift-giving and informality in economic transactions, semi-legal or illegal practices, clientelism, and bribery. However, they rarely face grand-scale corruption. One key reason is the participant observation method used by most anthropologists. In this method, it is difficult to have access over a long period to major political and corporate scandals. Therefore, grand corruption has largely remained beyond the scope of ethnographic investigations.

On the other hand, anthropologists find themselves in a difficult position when including corruption in different analytical types. Many anthropologists are suspicious of generalizations and are reluctant to draw general conclusions based on in-depth descriptions of different fields of research. Rather than categorize, anthropologists prefer to understand the meaning of a social reality by framing it in its socio-cultural context. The reluctance to divide corruption into clear-cut categories therefore comes from ethnographers' need to contextualize social phenomena. Rather than a static phenomenon defined in terms of 
belonging to previous categories, corruption can be understood as a dynamic process by analyzing the factors involved with a detailed description of its context. This processual view of a social phenomenon (such as corruption) was first built by anthropologists to understand socio-cultural change. Interested in the dynamics of socio-cultural change, anthropologists have deliberately studied social phenomena by focusing on the adaptation of the social system over time (White, 1959; Steward, 1955/1990). For White, culture is defined as the exosomatic (outside the body) means of environmental adaptation for humans (1959). The adaptation is then determined by environmental constraints. Following this line of argument, Steward coined the word "cultural ecology" to refer to the transformation of culture arising from the adaptation to the environment (1955/1990). Some anthropologists believe that with the same environmental limitations, some cultural patterns exist in different cultures, such as the structuralism of Lévi-Strauss. The goal of many anthropologists subsequently to the structuralist school is to search for forms of cultural diversity and to investigate them from a hermeneutical approach, which looks at the meanings and interpretations that local people give to their own social facts.

One example of the processual analysis of corruption is Yang's famous work on guanxi (personal connections) in China (1994). The term guanxi has been widely used to understand corruption, and has been studied by scholars not only in anthropology but also in management research (Xin \& Pearce, 1996; Lovett, Simmons, \& Kali, 1999). Participating in guanxi implies exchanging gifts, such as personal favours in business relationships. Yang treats guanxi not as a given set of cultural practices, but as a process, e.g. a historically specific product acquiring different meanings and deployments in different ethnic, class, gender, and regional dimensions. Yang is concerned about the uncritical use of guanxi and its recent development, guanxixue (the economy of personal connections), to describe corruption in China. She argues that capitalist development in the country has resulted in the interpenetration of public and private spheres. Alongside the Chinese culture transformation, guanxi has lost its beneficial role as a type of public good, and has come to serve the interests of only a few. The loss of the earlier semantic and social use of guanxi is 
explained by the consolidation of business networks and their influence in politics, and the way that corruption has expanded to become a larger process that benefits the elite.

Another example of the processual view of corruption can be seen in the field of development. Several ethnographic works have suggested that developmental aid increases opportunities for corruption. For example, anthropologists have highlighted that for development policies to be successful, officials have sometimes accepted widespread corruption. Bribes may become acceptable as long as aid funds can be used more or less efficiently (Hoag, 2010). Hoag highlights the widespread avoidance of talk about corruption in South African non-governmental organizations as part of their efforts to maintain the national social harmony (2010). With an environment characterized by both market liberalization and an increase in corruption, public debates about corruption become occasions to argue about the failure of development policies, market liberalization, decentralization, and privatization (Harrison, 2010).

Anthropology has thus developed a processual view of corruption that requires the scientist to deeply understand the environment and study corruption over time. To ethnographers, this processual perspective clearly reinforces the need to build long-term observations of corruption.

Defining corruption as a social process has also allowed anthropologists to highlight the diachronic dimension of social phenomena. Anthropology has a long tradition of historical analysis of societies, institutions, and other entities. For anthropologists, a synchronic analysis is not sufficient to deeply understand a society. From a social process perspective, human society is viewed as an ongoing process, as something that is becoming, rather than being (Shibutani, 1986). The study of history and social change allows us to understand the evolution of interrelationships among components of present-day society. Ethnographic studies have provided detailed descriptions of how new institutional, societal, and economic environments were being installed, imposed, and in several cases contrasted by local people. The processuality of postcolonial transformations has been captured by ethnographers in different contexts. In these situations, corruption practices develop via micro development projects, more macro aid and structural interventions, and the international growth of multinationals. The importance of a historical account of a society 
has been recognized by a number of scholars who discussed the similarities between anthropology and history (Lévi-Strauss, 1958/1963). By demonstrating the transformation of social phenomena, anthropology makes it possible to discern the key elements that underlie them and remain permanent during a succession of events. For Lévi-Strauss, "knowledge of social facts must be based ... from individualized and concrete knowledge of social groups localized in time and space. Such specific knowledge, in turn, can be acquired only from the history of each group" (1958/1963).

\section{The moral view of corruption}

Many social scientists from the West have criticized the immorality of corruption in developing countries by taking an overt superiority stance. A clear example of moralization can be seen in the work of some economists on the link between corruption and economic development. In his often-cited article, Mauro (1995) suggests that corruption lowers investment, and consequently economic growth. Anthropologists could interpret this thesis as judgmental because it suggests that developing countries are poor because they are dishonest. Anthropologists are very concerned by the dichotomy between economic development and level of corruption. There is an underlying idea of superiority between a "modern," "rational," and "transparent" West and a "traditional," "irrational," and "corrupt" rest. Anthropologists reject the moral dualism of corruption, according to which the decision to engage in corruption is bad and the refusal to do so is good. Rather than this Manichean view of corruption, anthropologists favor a nuanced approach by analyzing corruption from the point of view of the people concerned.

Although most social scientists agree on the damage that corruption can cause, the moralization of the debate can be problematic for scientific inquiry (Leff, 1964; Leys, 1965; Nye, 1967). Indeed, Leff has argued that the widespread condemnation of corruption constitutes a major obstacle to research because it hinders an objective examination of the concept (1964).

The debate on moralization has long existed in anthropology. In the 20th century, anthropologists such as Steward and Radcliffe-Brown rejected the idea that all human 
societies went through similar stages within an evolutional development of "civilization." This debate has led to the development of cultural relativism. As Franz Boas stated in 1887, "...civilization is not something absolute, but... is relative, and... our ideas and conceptions are true only so far as our civilization goes." For Boas, the world had different cultures, none of which was superior to the others, and therefore the societies could not be studied in their evolution according to the level of "civilization" that they possessed. Rather, each culture should be studied in its originality. Because cultural relativism is widely accepted among anthropologists, they have been uneasy about the Western-centric moralization of corruption. Taking the point of view of the indigenous peoples, anthropologists have tended to investigate corruption as a social phenomenon without explaining it through moral evaluations. This approach keeps anthropologists from condemning activities that are socially accepted by the local population. Anthropologists can therefore offer a rich analysis of corruption without focusing on moral implications. They could suggest that corruption should not be categorically seen as an "amoral behavior" that has developed solely within poor countries, but also in its complex forms and implications, in wealthier countries. In addition, corruption may be fostered by global governance, foreign aid, development projects, and global capitalism.

The issue of morality in relation to public officers who seek to serve their own interests through bribes, gifts, and favors is the subject of extensive debate in the ethnographic literature on corruption. According to the cultural relativism school, anthropologists do not see morality as a homogenous and universal phenomenon. This contrasts with the classical approach of Western political philosophy, which, drawing on Aristotelian traditions, sees moral integrity at the core of the development of accountable, rational, and democratic forms of governance (Rothstein \& Eek, 2009). Anthropological accounts of social morality draw more on its etymology, from the Latin mores, which means "social customs."

Anthropology provides a fresh approach to the moral aspects of corruption. The causal relationships that some scholars have identified between morality and economic development, social trust, social capital, and civil society (Banfield, 1958; Fukuyama, 1995; Putnam, 1995, 2000) have provoked major debates in anthropology, sociology, and political science (Silverman, 1965; Miller, 1974; Muraskin, 1974; Tarrow, 1996; Meloni, 1997). 
However, if ethos were the only explanation for problematic socioeconomic phenomena such as clientelism and corruption, there would be little need for ethnographic and empirical works on these issues (Banfield, 1991). These works would be expected to generate data confirming the origin and resilience of social practices such as familism, individualism, collectivism, and Protestant versus Catholic values. Nevertheless, many ethnographic works have produced empirical data that not only challenge these assumptions, but that also weaken the moral order approach (Pardo, 2004).

One problem with approaches focusing on the moral aspects of corruption is that these moral aspects tend to be socially and culturally specific. The moral order approach alone is not sufficient to understand corruption. For example, the role of the state, the local tradition of social movements, the role of social networks in framing identity, and the role of informal networks and exchange practices all have different meanings in particular contexts. The importance given to moral dimension in the analysis of corruption leads researchers to forget that corruption practices are strongly embedded in ordinary forms of sociability, influenced by culture. Thus, in the case of China, Yang has drawn attention to how different cultural backgrounds at different points affect the practice of corruption (2002).

Ethnographic studies of corruption contribute two original aspects to the debate on morality and corruption. The first is the notion that corrupt practices may not only be deemed as functional, but also as morally acceptable and even socially cohesive. In the case of India, for example, Visvanhatan contrasts the "warm nature of corruption" against the "cold of bureaucratic rationality" (2008). Dracklé also describes the case of Portugal, where corruption is driven by the conflicting claims and strategies of local agricultural entrepreneurs who spend much of their time attempting to gain access to "discrete bureaucrats" (2005). Investigating the case of China, Steinmüller describes the dichotomy, used by local scholars and intellectuals, between a modern, rational truth and a neotraditionalist truth (2010). However, he argues that the former often represents a façade of morality, because the bureaucratic sector is dominated by personal relationships and patronage. These relationships are rooted in Confucian ideals of connectivism, reciprocity, and personal ties of obligation (Yang, 1992; Smart \& Hsu, 2007). However, public discourses in China on morality are increasingly informed by Western ideas of rationality that 
expressively portray "traditional" customs as forms of "state involution," which could lead to the coexistence of two conflicting sets of moralities on corruption.

Anthropology can also contribute to corruption research by studying corruption in contexts of rapid economic and political institutional transformation. A typical example is corruption at a time of radical change from a communist to a democratic system (Venard, 2009). Such contexts generate different, often conflicting moralities. One common ethnographic finding is that the diffusion of neoliberal values erodes and transforms the existing moral order to the point of transposing social values. This perspective therefore offers a dynamic approach to morality. For example, Rivkin-Fish studied corruption in the Russian healthcare system (2005) and found that, unlike corrupt practices under socialism that involved working "on the side" to fill gaps in the centrally planned economy, corruption in post-socialist Russia involves providing spaces for generating mutual trust (Rivkin-Fish, 2005). The market economy has resulted in a diminished space for social interactions, and corruption is used to fill this gap. The gift and bribe system has also been strongly affected by the conspicuous introduction of money into these transactions in recent years. Local perceptions of what constitutes moral conduct are changing, and practices that were once socially acceptable in Russia are becoming ethically problematic as they come to involve money. As has been observed in several other ethnographic contexts, this trend reveals a new tension between (petty) corrupt practices that are viewed as socially acceptable and practices in which money and sudden gain become manifest, and which are therefore perceived as immoral.

In one of the most theory-oriented anthropological contributions to the study of corruption, Oliver de Sardan uses the notion of the "moral economy" to refer to the African case (1999). For him, the key to understanding the widespread diffusion of corruption in Africa is to consider its "banalization" and "generalization" in everyday practices and discourses. He sees corruption as a realm of rumour and gossip, where the political and the social become intermingled and semantically determined. As a result of a number of culturally constructed practices (gift giving, brokerage, solidarity networks, predatory authority, and redistributive accumulation), corruption becomes a commonly accepted practice. 
Hasty (2005) makes a similar point in his study of anti-corruption officers in Ghana. During his fieldwork, Hasty had the advantage of being both a journalist and a trained anthropologist. His profession gives him access to individuals and documents that were inaccessible to other ethnographers. He describes the personal characteristics and actions of bureaucrats working in anti-corruption offices who strive to maintain self-discipline and integrity in spite of the many forms of "desire" that can drive corruption. Hasty describes officials who refused to take gifts of food and drink (except for soft drinks), despite this being extremely common in several African contexts. These officials are seen as retiring, antisocial, and morally suspect by the local population. As a matter of fact, their behavior contrasts with locally accepted standards of morality, in which conviviality and participation in lavish banquets, among other practices, is seen as a natural and morally unproblematic aspect of material wealth and power.

In the case of Italy, Pardo (2004) and Miller (2004) underline how in southern Italy, the use of money to pay for the services of public officials (such as Neapolitan doctors) leads to a delicate balance of long-term and short-term moral commitments. Miller is a magistrate with vast experience in Italian corruption cases. He suggests that the exchange of power for money is viewed as immoral conduct (2004). However, this immoral conduct could be classified into two types: short-term, which is merely instrumental, and long-term personal relationships, which are more morally acceptable (Miller, 2004: 53-55). This is supported by findings in Eastern Europe (Humphrey \& Sneath, 2004; Rigi, 2004). Describing the case of Latvia, Sedlenieks suggests that corruption becomes morally acceptable at a social level when there is extensive use of monetary remittances (2004). In Latvia, money is considered "fertile," and corruption is morally acceptable when it brings about long-lasting personal relations. Petty corruption can be more easily condemned and considered "barren money" when it benefits only the individual rather than the social community. Similar points are raised in Latin American contexts, such as Mexico and Colombia, where the public hope is that social benefits will arise from the political dynamics of corruption (Gledhill, 2004; Lazar, 2005). In all these cases, market values contrast and intertwine with existing moral orders, calling for new and often conflicting interpretations of what constitutes moral conduct in relation to corruption. 


\section{The anthropological methodology of investigating corruption}

Since the 1970s, there have been intense debates in anthropology on the methodological and ethical issues associated with research. Anthropology has provided methodological tools to uncover the visible manifestations of corruption. Anthropological accounts of gift-exchange processes, reciprocity, redistribution, informal economic transactions, moral economy, clientelism, nepotism, cronyism, and social networks highlight some of the areas in which the discipline has been a pioneer. For example, the anthropological debate stemming from the well-known essay by Marcel Mauss on the gift was key to the foundation of the social theories of reciprocity and gift exchange (1923/2005). Since then, anthropology has engaged actively with all of these social phenomena because they are part of the social realities the ethnographer encounters during fieldwork. It is clear that ethnographers undertaking observations may face a gift/countergift relationship with the indigenous people similar to the description offered by Lévi-Strauss (1955/1973). The practice of gift exchange enables anthropologists to build a stable and long-term relationship with the local inhabitants.

Since the seminal work of Malinowski (1922), various anthropologists have advocated the importance of ethnographic fieldwork. Ethnography aims to record as accurately as possible the ways of life of various groups (Lévi-Strauss, 1958/1963). The typical method is participant observation, first coined by the anthropologist Malinowski. This method entails observing people over a long period of time. The famous American anthropologist Philippe Bourgois, stated that "traditional social science research techniques that rely on Census Bureau statistics or random sample neighborhood surveys cannot access with any degree of accuracy the people who survive in the underground economy... The participant-observation techniques developed primarily by cultural anthropologists since the 1920s are better suited than exclusively quantitative methodologies for documenting the lives of people who live on the margins of a society that is hostile to them... With this goal in mind, I spent hundreds of nights on the street and in crack houses observing dealers and addicts. I regularly taperecorded their conversations and life histories... I also visited their families, attending parties and intimate reunions..." (1995/2003). In his last book, Bourgois presented a study based on 
fieldwork spanning 12 years (Bourgois \& Schonberg, 2009). This duration of research on the same social reality is alien to most scholars from other disciplines.

The fieldworker lives in the society and is involved in as many activities as possible. This involvement gives him or her insights into the local culture's point of view and value system. The intense use of participant observation by anthropologists is partly the result of the observed reality when anthropology was created. In fact, earlier ethnographers surveyed oral societies, which, by nature, had no written documents. To overcome this barrier, anthropologists had to rely on long-term observation and many interviews. The analogy with corruption is interesting because being commonly forbidden, no written documents exist on the subject.

For anthropology, the aim of ethnography is not only to precisely record information, but also to take the position of the observed. For instance, Lévi-Strauss stressed the importance of studying a phenomenon from the perspective of the "indigenous" (1950/1987), and suggested that to understand a social fact, it is crucial to observe it as a local person and not only as a scientist. As Lévi-Strauss suggested, "...it is necessary to apprehend totally the object from the outside, and as an object including the subjective capture (conscious or not conscious) that we should have if, only humans, we will be living the object as a native instead of observing it as an ethnographer" (Lévi-Strauss, 1950/1987). Malinowski also believed that an ethnographer can "grasp the inner meaning" (Malinowski, 1922/1984). Geertz offered an interesting image illustrating the importance of the view of the observed by describing the anthropologist as reading over the shoulder of the studied population (1973).

Ethnography allows a critical, in-depth investigation of phenomena through the collection of rich, ground-level data. Corruption is a social practice and therefore can best be observed from an inside perspective (Kerby, 1991). For anthropologists, understanding corruption implies becoming intimate with the phenomenon and being with the people involved day after day. Anthropological fieldwork is especially relevant considering the criticisms that have been made of large-scale empirical studies of corruption. These large, cross-national studies often use a universal definition of corruption across contexts, when in fact different cultures often have particular local understandings of the concept that make international 
comparative analysis difficult. In contrast, ethnography is a fine-grained approach that develops through the researcher's constant interactions with local people. The construction of mutual trust is an important factor in the success of fieldwork. This focus on the local context partly explains the "added value" that anthropology can bring to the study of corruption. The insider point of view could also allow anthropologists to change the focus of research on corruption, from the perpetrator to the victim. An anthropological perspective could then offer a response to the problem of ethnocentrism in many studies of corruption, and could help to shed light on the views of the victims of corruption, especially in emerging markets.

As mentioned earlier, a key idea of ethnographic work is to live with the natives. Ethnographers will try to find informants, who constitute a crucial link between the observer and the observed society. The informant is much more than a person giving information; he or she is a "translator" and the "medium" between the observed society and the ethnographer. The informant can bring clarify the meaning to various components under investigation. Fieldworkers should learn the local language and the rules of behavior to become unobtrusive, so that the informants will forget they are being observed and act normally. Ethnographers should also record any details, from casual conversations to life history accounts, by observing personal disputes. Data are collected mainly through observation, day-to-day conservations, and interviews. Anthropologists struggle between the need to be neutral scientists (but foreign to the people) and the importance of getting close to the observed people through friendship and mutual trust. Considering the need for a broad collection of information, the interviews done by ethnographers are ideally unstructured and follow the path of a conversation (Wolcott, 1995). For example, in the course of the author's field research on corruption, after a number of meetings with different people, ranging from local inhabitants to politicians, administrators, and company managers, it became clear that the more the word "corruption" emerged, the more hesitant some interlocutors became to answer questions. However, the opposite tendency was also true. Some informants, in particular members of nongovernmental organizations, were eager to discuss corruption. In such circumstances, the ethnographer might gain a distorted 
view of the reality because of the reluctance (or lack thereof) of the informants to address the topic. The ethnographer's strategy was to elicit discourses and comments on corruption in indirect ways, testing the relevance of the topic and the forms and contexts in which they emerged, rather than focusing only on concrete actions and corrupt deeds. This approach often had the unexpected consequence of making interlocutors reflect on the real social meaning of corruption, its costs, and the effects it had on the governance and business spheres.

Conducting fieldwork on corruption entails some difficulties. First, the hidden nature of corruption makes participant observation difficult. The degree of invisibility of corruption depends on the magnitude of the phenomenon (petty/large transactions), the cultural diffusion (individual act/local or nationwide practice), and the degree of acceptance of corruption in the social and legal environments. When corruption is endemic, honesty may be the deviant behavior. If the invisibility varies, observing corruption is difficult. Anthropologists collect 4 types of descriptions of corruption: personal anecdotes, biographical trajectories, polyphonic case studies, and bureaucratic itineraries (Blundo, 2007). Personal anecdotes are the incidents of corruption faced by the researcher. They are collected during on accidental occasions. Biographical trajectories are interviews with informants describing their lives and experiences with corruption. Informants typically comprise policemen, judges, and customs officials. Polyphonic case studies are built by anthropologists describing a case of corruption from various information sources, such as desk research, observation, and interviews. The idea is to use multiple techniques of inquiry to get a clear view of the corruption practices prevailing. Bureaucratic itineraries involve analysis of real bureaucratic activities from various angles. For example, a researcher could try to survey the process of getting a physical good out of an African port.

Second, a major constraint for ethnographers is the risk of ethnocentrism. Anthropology was the first social science to introduce the concept of ethnocentrism (Sumner, 1906). Condemning the idea of Western superiority, Sumner introduced the concept of ethnocentrism as the tendency of one observer to see another culture from the point of view of his or her own, which leads to overestimation of the culture of the observer and the perception of biases and stereotypes regarding the observed culture (1906). Evans-Pritchard 
also believed that anthropologists should analyze societies based on the local communities' viewpoints, rather than their preexisting ideas (1937). The importance of the observer in the scientific process has been questioned repeatedly by anthropologists. For example, one village in Mexico was surveyed by two anthropologists: Redfield in the 1920s and Lewis 17 years later, in the 1930s. They made opposite interpretations regarding the harmony of the village. Considering the controversy, Redfield replied, "the great part of the explanation for the differences between the two reports... is to be found in the differences between the two investigators. I looked at certain aspects... because they both interested and pleased me" (1960: 135). Anthropologists have long recognized that other cultures should not be judged solely by the values and standards of the researcher's own, and that they must transcend their personal point of view-their ethnocentrism. However, as Geertz argued, all ethnographic presentations are to a degree "allegoric," implicitly confirmatory, or illustrative of the anthropologist's own worldview and values (1973). In response, anthropologists have developed methods to protect them from their own subjective assumptions and value judgments (Pelto et al., 1970/1996). These include long periods of research, the use of participant observation (with multiplication of social interactions between the anthropologists and the observed), comparison, and personal diaries.

In a number of her works, British anthropologist Mary Douglas has attempted to deal with ethnocentrism convincingly by adopting a comparative perspective to the study of human society (Douglas, 1966, 1970, 1978). Comparison allows the anthropologist to escape the ethnocentrism-relativism trap by providing a scientific basis for understanding cultural differences without "essentializations." Drawing from the classical sociological insights of Emile Durkheim, Douglas maintained that cultural variations, which she termed "biases," are outcomes of individuals' social responses to the range of choices that are given within a particular culture. To account comparatively for these responses, Douglas introduces two dimensions: grid and group (Douglas 1978). Grid is the sum of the institutional limitations (from market to politics, laws, and customs) that society imposes to delimit the range of individual choices. Group is the sum of social pressures, forms of arrangements, and interaction patterns among people in a society. In this perspective, ethnocentrism has little room to develop, because the comparison of responses to different forms of pressures is inherently a universalistic approach. 
The ethnographer's personal diary is also a powerful tool for avoiding ethnocentrism and the subjective interpretation that is linked to it. During fieldwork, the ethnographer writes a specific diary on the research, not recording the interviews and observations, but his or her day to day personal experiences, doubt and feelings. For example, when experiencing cultural shock in a foreign culture, ethnographer describes this emotion, thereby distancing himself or herself from it. The diary reduces the tendency towards ethnocentrism by making explicit the researcher's emotions, attitudes, feelings of judgment, and perceptions of superiority toward the natives. By being able to make the ethnocentrism explicit in the diary (often much longer after the field work), the ethnographer can consequently reach a more objective interpretation of the social reality. Third, the conduct of fieldwork could also imply ethical issues in surveying corruption. An ethnographic study of corruption could raise ethical concerns for anthropologists about ensuring the anonymity of informants, the use of gathered data concerning a forbidden behavior such as bribery, and the anthropologist's role as an "intruder" in the observed social reality (Atkinson \& Hammersley, 1983; Clifford \& Marcus 1986). The largest professional associations in cultural (American Anthropological Association) and social anthropology (European Association of Social Anthropologists) have clarified the deontological conditions under which fieldwork research needs to be undertaken. ${ }^{1}$ One of the most important elements of these ethical codes concerns the need to avoid exposing informants to any form of harm as a result of the use of fieldwork data. Anthropologists are under a paradoxical injunction regarding fieldwork leading to the discovery of corrupt practices. On the one hand, one goal of anthropology is to carry out indepth qualitative analyses to reveal the details of corruption as an illicit phenomenon. On the other hand, the ethnographer cannot place the people they observe in danger. By the very nature of their discipline, ethnographers make detailed inquiries into behaviors, interactions, thoughts, and symbols, and when associated with corruption, this information could put their respondents at risk. After having overcome the barriers of observation, the problem is then to disclose illegal activities. Punch stressed the risk of criminalizing the practice observed (1986). Typical questions in the study of corruption include: Could the

\footnotetext{
${ }^{1}$ See, for instance, http://www.aaanet.org/committees/ethics/ethcode.htm for the American Anthropological Association and http://www.easaonline.org/index.shtml for the European Association of Social Anthropologists.
} 
researcher disclose informants' wrongdoing without harming him or her? And could the disclosure destroy the trust between the observed and the scientist? 


\section{From a cultural perspective to a holistic analysis of corruption}

Early in the development of anthropology, a focus was culture since it is what distinguishes humans from animals. It refers to people's capacity of to build classifications around their experiences, create symbols related to their classification, and transmit this knowledge to others. Lévi-Strauss' study of structuralism is one example of such a focus. Tylor, an early anthropologist, defined anthropology as the study of culture, defining culture as "the complex whole which includes knowledge, belief, art, law, morals... capabilities acquired by man as a member of society" (1920:1). In the $20^{\text {th }}$ century, the anthropologist Clifford Geertz also broadly defined culture as "a system of inherited conceptions expressed in symbolic forms by means of which men communicate, perpetuate, and develop their knowledge about and attitudes toward life" (1973).

Given the scope of anthropology, it is normal that both ethnography and anthropology are holistic in their approach to social practices, which are studied in the context of many other activities, statuses, and roles (Plattner, 1989). In this respect, a crucial concept in anthropology is the total social phenomena of Mauss (1923/2005). According to Mauss, a total social fact concerns the whole of society and its institutions: economic, political, religious, legal, and so on. Lévi-Strauss, considered Mauss's essay a masterpiece and a classic in anthropology not because he introduced new facts, but because for "the first time in the history of ethnological thinking... an effort was made to transcend empirical observations and to reach deeper realities" (1987: 38). Although suggestive in its original form, one of Mauss's key ideas is that anthropologists should have a holistic view of social facts, looking at the entire society as a single component. To describe the holistic nature of anthropology, Geertz used the expression "thick description," which he borrowed from Gilbert Ryle (1973). The term "thick description" seems to suggest the importance of detailed collection of information. It can be considered an anthropological method of explaining with as much detail as possible the reason behind human actions. Beyond that, however, thick descriptions of the anthropological reality are the depiction of multiple meanings, by investigating the plural and interconnected aspects of the studied reality. A given human activity can be interpreted at various levels. Geertz stated that the anthropologist must grasp "a multiplicity of complex conceptual structures, many of them superimposed upon 
or knotted into one another, which are at once strange, irregular, and inexplicit" (1973:10). Geertz (1973) illustrated this idea with his description and multiple interpretations of the cockfight in Bali, with which he was able to create a meta-social analysis of the Balinese society while looking at a single manifestation.

Whereas many scholars, particularly economists, are more interested in the illegality and immorality of corruption practices, anthropologists consider corruption part of a larger set of social actions. An important argument in favor of an anthropological approach to corruption is that it can focus on undertaking a cultural rather than a moral analysis of the practice. The added value of an anthropological perspective in corruption studies is therefore linked to the theoretical priorities of anthropology and its focus on the ethnographic study of culture. Thus, anthropologists not only deeply analyze corruption practices, but also try to look at the link between corruption and other elements of the society. The term "elements" may seem broad, but this shows the willingness of anthropology to spread its inquiry to "unexpected corners" of research. For example, in a corruption practice, anthropologists could analyze the power structure within the whole society. Corruption could be an act of domination by members of the economic elite over bureaucrats and other lower classes. At the same time, corruption could be seen as a gift-exchange component, where the financial transfers allow testing of the reciprocity in the exchange, creating both dependence and harmony between social actors.

Anthropologists are always looking beyond the social focus they initially had in mind. When examining corruption practices, they try to develop an understanding of the whole society. For example, during the observation of corruption, the ethnographer will take into account the holistic nature of anthropology when collecting information and analyzing the different manifestation of interrelated human activities. Thus, the anthropologist could interpret corruption at the same time from many dimensions: as an exchange, an illegal action, a political relationship, and a cultural routine.

\section{Governance and Corruption}


One example of the holistic approach of anthropology is the political analysis that anthropologists perform when surveying and analyzing corruption, especially with regard to governance. Two main orientations have emerged that attempt to assess the impact of corruption on economic development, governance, and the capacities of the state. The first orientation, dominant among economists, argues that the positive capacities of the state are those that maintain market efficiency, restricting state intervention in the provision of public goods. For example, Acemoglu and Verdier assert that cycles of corruption can develop and become self-perpetuating. They argue that "corruption is often unavoidable because governments distort the allocation of resources, and corruption is the way that the market bypasses the regulations... the government intervenes to redress market failures, and corruption emerges as an unpleasant side effect of necessary intervention" (2000). They suggest that excessive state control inhibits development because it fosters irregular practices such as clientelism, informality, and lack of transparency. This argument has been used to explain the widespread presence of corruption in authoritarian regimes, as well as in monopolistic states, in which governments have been described as kleptocratic, rentseeking, or predatory. From this perspective, corruption is construed as an outcome of widespread interpenetration of economic and political spheres, which reduces competition, increases privileges, and leads to the creation of powerful elites and cliques (Sun, 2004; Johnston, 2005; Varese, 2005 ; Venard \& Hanafi, 2008).

The second orientation shares some of the views of institutional economy; for example, that good governance is a prerequisite for economic development. However, this approach suggests that excessive decentralization of governance is also a breeding ground for corruption. In some cases, for example, the weakness and fragmentation of postcolonial states results in power struggles involving multiple actors, which leads to the spread of corruption. Some authors describe such countries as "neo-patrimonial" or "belly states" (Blundo et al., 2006). Anthropology has provided sophisticated ethnographies of the state in relation to a number of political and social phenomena and cultural practices (Sharma \& Gupta, 2006). Following a Foucauldian interest in issues of power, knowledge, discourse, and governmentality, ethnographic accounts of the role of the state in relation to corruption have taken a number of standpoints (Shore \& Wright, 1997; Bellier \& Wilson, 2000; Holmes, 2000). 
Three main perspectives emerge from our literature review: normative, hermeneutical, and transactional.

\section{Normative Approach}

This approach analyzes the legislative and normative functions in which corruption takes root in different societal contexts. In the business ethics field, normative ethics investigates the set of questions that arise when deciding how one ought to act from a moral point of view. Using a different meaning, we take the term "normative functions" in its sociological sense. From this perspective, corruption is seen as a violation of a social norm. The first scholars on the topic stressed the functions of norms to explain human behaviors (Durkheim, 1950; Parsons, 1937). They had a very universal view on the matter. As mentioned earlier, ethnologists comparing cultures soon realized that rather than universal norms, various cultural norms existed in different societies, and that diverse social norms function within a culture (Geertz, 1973). This diversity of norms is well documented in the sociology and management fields, in particular among the neo-institutionalists (DiMaggio \& Powell, 1983; Greenwood, Oliver, Sahlin, \& Suddaby, 2008). The original approach of anthropology is to use this standpoint to analyze corruption. Misangyi, Weaver, and Elms have proposed a similar perspective that aims to understand the complex institutional logics explaining corruption, in an effort to counter this social phenomenon (2008).

Following this line of argument regarding norm diversity, anthropology has built a strong critique of the Western dichotomy of state and society, and developed a dual perspective on the role of the state. In such studies of corruption, the state is portrayed either as a weak actor that attempts to enforce anti-corruption norms and laws, or as a legislative agent of ad-hoc norms that increase unaccountability.

In a recent contribution to this approach, Nuijten and Anders posited out that the common Western-centric notion of corruption, grounded in the dichotomy between public and private interests, is of little help to anthropological investigations (2007). They agree with the legal anthropological perspective that law is plural and profoundly influenced by social processes (Moore, 2000). Corruption and law are not opposites, but rather constitute one another. The possibility of transgression is always present in law. Thus, Nuijten and 
Anders describe corruption as "the secret of law", defining the possible areas for the application and intervention of the law but also allowing for its transgression in society. Corruption could thus be seen as a different, secret form of legal order (Znoj, MacNaughton, \& Wong, 2007).

Because law is plural, an approach that sees law as the only cure for corruption is misleading. Pardo makes a similar point from a different angle (2004). For him, political and legal conceptualizations of corruption and its effects within state boundaries are marked by inherent ambiguities. Pardo recognizes that anthropology is confronted with the difficult task of finding a balance between historical variations on one hand and universal aspects on the other. He argues that one of the limits of the anthropology of corruption has been its cultural particularism, and proposes two ways to overcome this impasse. The first is to view morality (see our previous discussion of the morality of corruption) as a battlefield in which socially constructed ideas of legality and illegality conflict with universal claims of legitimacy. The second is to investigate the role of the state and how it may claim to be above corruption, even while it directly participates in such corruption by encouraging "institutional blindness to allow the interests of the elites" (Pardo, 2004: 6). The state may even legitimize the ambitions of corrupt politicians, who claim to restore moral conduct to political action but instead pass laws that make the border between legality and illegality opaque. From this perspective, the state is an active participant in setting the agenda for corruption.

Law creates the sphere of legitimacy through which corruption is accepted or rejected, conceived of, and exploited by those in power. Various authors have stressed this point in different settings, such Hsu and Smart (2007) for China, Corbin (2007) for Spain, Dalakoglou (2010) for Albania, Goldstein (2003) for Bolivia, Levine (2004) for South Korea, Hoagh (2010) for South Africa, Blundo (2006) for Senegal, and Scott (2010) for Taiwan. This anthropologist's view is in line with the work of economists who show that laws and rules can be implemented to facilitate corruption. Thus, the possibility of receiving bribes may be an incentive to create restrictions on economic development (Kurer, 1993). For example, a civil servant may introduce a new complex, complicated administrative rule and slow down the decision process to extort a bribe (Myrdal, 1968). Lui developed a model showing that 
corruption could lessen the time spent in queues, and that bribes could be an incentive for civil servants to improve processes in low-performing administrations (1985). Some scholars have argued that restrictions are not exogenous to the system, but rather "part of the builtin corrupt practices of a patron-client political system" (Bardhan, 1997). Some civil servants may organize the entire bureaucratic system (with many restrictions) to force the population to use corrupt practices in their relationship with the public administration. For example, the anthropologist de Soto showed that it took teams of researchers an average of 300 full days and six hours to obtain all the permits to start a small business in Peru (1990). In such a situation, illegal activity and corruption become the norm for entrepreneurs.

\section{Hermeneutical Perspective}

In contrast with the social norm approach, the hermeneutical perspective looks at the sphere of governmentality rather than governance, exploring ground-level efforts to interpret political power. Drawing from a rich theoretical background that originates in the works of Michel Foucault, Clifford Geertz, Victor Turner, and, recently, John-Jean Comaroff and Michael Herzfeld, this perspective aims to detect the discursive function of corruption. Foucault coined the term "governmentality" (from the words "governing" and "mentality") to highlight the interdependence between the exercise of government and the mentalities that shape this exercise. Governmentality is a "guideline" for analyzing the links between forms of government and modes of thought about governing (Foucault, 1991). To quote Foucault, governmentality is "an art of governing that finds the principles of its rationality and the specific domain of its applications in the state" (Foucault, 2007: 364). The tradition of focusing on discourse is as ancient as anthropology. As mentioned earlier, the first ethnographers studied oral societies that lacked written documentation. Anthropologists had to collect and interpret oral traditions. For example, Lévi-Strauss emphasized the revolutionary role of structural linguistics in anthropology (1958/1963).

For anthropologists, the rhetoric of the elites and the general population on corruption is as interesting as its practice. A strong argument in favor of analyzing the discourse about corruption is the fact that the perception of corruption is crucial for its understanding. Indeed, following Becker's work on deviance (1963), we could stress that corruption is an act to which this label was successfully applied. In a given context, social actors could decide 
whether an act is a corruption practice or not. They will also label this practice as illegal or immoral or not according to the situation. For example, in the protected space of an office, a civil servant could describe a bribe as a monetary exchange to facilitate relationships. In front of a judge, the same civil servant will recognize his or her wrongdoing. Further, the condemnation of corruption but also in general its perception are culturally embedded (Blundo, 2007).

Following Foucault's work on the discursive expressions of power, anthropologists have studied the communicative aspects of corruption. Ethnographers have identified two contradictory effects of using the term "corruption" in the public domain. On the one hand, widespread public discourse about corruption may contribute to the strengthening of social ties of belonging, sharing, and common identity. This may be accomplished when people join together to denounce corruption and the damage it can do to the social fabric of society. On the other hand, exposure to frequent public denouncements of corruption can increase cynicism and decrease trust in political institutions, as political scientists have demonstrated, for example, in the case of Russia (Venard, 2009). While the second observation can be easily measured through quantitative methods, the first is harder to detect.

For anthropologists, corruption is a "language" or a "meta-language" that is in everyday use, and public discussion of corruption provides opportunities for citizens to communicate anxieties, concerns, and ideas about their society (Gupta, 2005). From this perspective, the discourse about corruption can be seen as an attempt to control threats to social and normative orders (Parry, 2000). Similarly, the above-mentioned sociability that ethnographers attribute to petty corruption and informal practices is observed in the case of widespread corruption talk (Gupta, 1995; Corbin, 2004; Humphrey \& Sneath, 2004; Znoj, 2007). In some countries, people talk freely and abundantly about corruption. For example, Gupta described the intense dialogues of Indians regarding bribery. Indian media, government agencies, NGOs, and people seem to engage in endless discussions on corruption (Gupta, 1995). These dialogues show that corruption can be an opportunity for communication, whether in an open or a concealed manner. When the conversation is hidden, the very secrecy and conspiratorial nature of this practice adds to its communicative 
power, and creates social differences between those unable to access information on corruption and those possessing such knowledge (Andres \& Nujiten, 2007; Turner, 2007).

Anthropologists have reported other cases in which the communicative power of corruption is part of a deliberate political strategy. In their study of anti-mafia movements in Palermo, Jane and Peter Schneider (2005) describe a case in which criminal activities and extortion were used as powerful cognitive schemas in which to frame the difficult consolidation of civic organizations. For some anti-mafia activists, discourses on criminal activities and corruption have a strong political significance in a region such as Sicily, where it is important to avoid speaking about it, in line with the dominant value of omertà (conspiracy of silence). Similarly, Torsello showed how, in the new EU member states of Central Eastern Europe, denouncing corruption was deployed as a (more or less) successful communicative strategy by environmentalist movements seeking to garner public participation in their protest campaigns against transport development projects (Torsello, 2012). Initially, the communication of environmental movements used the preservation of nature as the main argument in their struggle against EU and state transport development projects. When the complex implementation of these projects resulted in corruption, some civic organizations quickly embraced this new discursive "weapon."

The importance given to discourse in anthropology is also understandable from a methodological point of view. Because corruption is very difficult to observe directly, informants are required to describe their experiences. When anthropologists interview protagonists of corruption practices, they collect an interpretation by the informant regarding corruption. The informant recounts his or her experience and builds a discourse using his or her system of values and social norms. This discourse may range from a simple description to a more complex explanation, and even a complete justification.

Corruption is one of the ways in which people make sense of politics and the state. It is akin to a conversation, to a ritual, or for some, even to witchcraft. The comparison of corruption with witchcraft has been raised by a number of anthropologists (Bähre, 2005; Bubandt, 2006; Blundo, 2007; Turner, 2007; Rudnyckyj, 2009). There are two ideas underlining this association. The first is that corruption, like witchcraft, can be a way to re- 
establish a distorted moral and symbolic order, particularly in conditions of profound institutional transformation such as in post- or neo-colonial economies. The second refers to the secrecy of corruption practices, which, like sorcery, help users gain access to power and hence demystify the secrets through which state power functions. The focus of analysis should not be whether the state has been able to set the boundaries between legality and illegality or between morality and immorality, or whether the state uses corruption to obtain legitimacy. Instead, anthropologists in this field recommend focusing on the discursive practices of corruption to understand its role in governance.

This hermeneutic approach is present in the work of Gupta, who provides one of the most refined contributions to the anthropology of corruption (1995; 2005). Gupta describes how local citizens in India use corruption as a form of discourse to obtain information, which will allow them to access otherwise inaccessible benefits. He identifies a political strategy devised by citizens, which involves seeking information on ways to bribe successfully, how much money is to be paid, and which interactional conditions require bribes to access state services. Gupta's work highlights the need to differentiate between two discursive uses of corruption in relation to governmentality. The first concerns the process of information seeking about whom, how, and when to bribe. The second corresponds to public discourse, i.e. the ways in which ordinary citizens address corruption in their everyday lives and how their denouncements influence social ties of trust and solidarity.

Gupta shows that the state connects with ordinary citizens via face-to-face relations with local officers. These local officers are able to use clientelistic and personal networks to perpetuate their power. This situation contrasts with the general Western view of the opposition between state and society. In India, corruption is the space in which the state intertwines with social practices, relations, and even moralities. In this approach, the state may appear much more disaggregated and decentralized than when viewed through the traditional lens. However, reference to corruption in public discourses, especially by politicians, brings the state back into play, as Bailey (1969) and Boissevain (1974) have shown. The discourse about corruption by politicians, NGO leaders, and social activists could allow them to improve their public image and thus reinforce their power and influence (Scott, 1972). Some ethnographic studies have stressed this point (Wade, 1982; Kondos, 
1987; Price, 1999; Ruud, 2000, 2001; Sewanta, 2009; Torsello, 2012). For example, in an empirical study conducted in Nepal, Sewanta demonstrated how local citizens use corruption at a discursive level to differentiate between the performances and capacities of a number of institutions from the police force, to health, education, and postal services (2009). Like Gupta, Sewanta suggests that this discursive use of corruption does not necessarily deter local citizens from engaging with state officials, but rather works as a frame of reference to establish effective practices under such conditions.

\section{Transactional Approach}

The third perspective seen in the study of corruption is transactional. This approach views governance as an interaction between different levels of political decision making. A number of ethnographic studies have argued that corruption signifies an inefficient relationship between the state and local government, sometimes due to an incomplete or excessive bureaucratization process (Prato, 2004; Zerilli, 2005; De Vries, 2007). The interactions between the state and the local governments could be so conflicting that they view each other as competitors. This competition has been the subject of analysis in reference to different socio-cultural contexts, for instance in China (Smart \& Hsu, 2007), Indonesia (Bähre, 2005; Bubandt, 2006), and Latin America (Lomnitz, 1995; Goldstein, 2003). In an ethnographic study, Torsello analyzed the transactional nature of corruption, stressing that corruption is the result of competition between diverse political bodies (2012). He found that focusing on the interactions was useful in understanding the spread of corruption in relation to European Union (EU) enlargement politics (Dracklé, 2005; Shore, 2005, Torsello, 2012). These interactions take the form of a competition between state and local bodies to get European Union funding. In the late 1990s, Eastern European countries entered a phase of institutional transformation to be accepted to the EU. Focussing on the effects of EU structural transport projects in Central Eastern Europe, Torsello found that public debate on corruption was an opportunity to discuss the problems of delocalization of power toward local bodies and the dissatisfaction with strong state authority. These European countries had already experienced authoritarian governments during the communist period. In such situations, the focus of public denouncements of corruption is not the state but local governments, which, in the years preceding EU accession, 
implemented wide reforms to decentralize administration, and which are believed to use corruption to reform the state (Torsello, 2010).

As Blundo stated, to decriminalize corruption (and subsequently access information about it), it should be considered at the time of transaction and reintegrated in a more ordinary social space (2007). Indeed, corruption should be analyzed as a component of a larger ensemble of transactions between the state and individuals, which include various social relations of extortion, mutually beneficial transactions, along with exchange, reciprocity, negotiation and gifts.

\section{A summary of the anthropological contributions to corruption research}

Anthropology offers fresh insights for the study of corruption at various levels. One important contribution is that it deliberately does not provide a universal definition of corruption. Rather, anthropologists prefer to build an ad hoc definition using the point of view of the observed. Most scholars would be disoriented and surprised by such a lack of prior definition of the concept under scrutiny. Young ethnographers are often advised to start their fieldwork inductively, by rejecting preconceived notions and starting the research with in a very inductive manner. Anthropologists believe in the richness of inductive research, which implies mainly making observations and analyses from the natives' point of view. As a result, anthropologists have avoided producing typologies of corruption. Instead, they have focused on treating corruption as a process. This processual view of corruption has two advantages. First, it emphasizes the environment of the corrupted practices. To understand any social phenomenon, anthropologists must understand its environment, especially its socio-political context. Second, the processual perspective implies seeing corruption not as a static phenomenon, but in relation to accounts and conditions of social transformation, globalization, and development. The novelty of anthropology is not that it offers a temporal evaluation of corruption practices, but rather that it claims that major social, economic, and institutional transformations may foster or require corruption.

Anthropology has also developed an original approach to investigating the morality of corruption. Many social scientists start their research by condemning corruption per se. 
For example, various economists have given a moral judgment to corruption, condemning this illegal practice. When a large stream of research in economics stresses that corruption hinders development, it could be implied that poor people are poor because they are corrupted. This condemnation does not add to the scientific debate and to the understanding of the phenomenon. Ethnographers, facing a huge diversity of cultures in their work, do not easily disentangle from cultural relativism. The main argument is that because moral values are dependent on the culture, and because cultures are plural, moral values are also diverse, which makes moral judgments culture-dependent. Instead of being destructive, corruption could be morally acceptable and even socially cohesive in some societies. For example, because a bribe could be part of a gift exchange implying reciprocity, cooperation, and collaboration, ethnographers have stressed that corruption can foster social harmony and cohesiveness. Ethnographic research on corruption has also shown that individuals face conflicting moralities, especially in periods of rapid economic and political transformation. Anthropologists have also emphasized the dynamic nature of the morality of corruption, especially at times of rapid social transformation. In such situations, anthropologists see corruption as a heterogeneous rather than homogeneous phenomenon, accepting a variety of meanings and forms of the practice.

Their contact with different societies has led anthropologists to develop ethnography to uncover rich and complicated social phenomena. Participant observation was first coined by ethnographers. As for other qualitative research methods, participant observation allows the researcher to observe and collect a large amount of rich information. Of course, anthropologists use other methods of inquiry, depending on their research question. When possible, they try to undertake long periods of fieldwork to develop a more intimate relationship with the field. To survey a hidden behavior such as corruption, this long-term inquiry enriches the information collection and the analysis. A qualitative approach is the main tool of anthropologists in corruption research. While many researchers in other social sciences mainly use quantitative methods to survey corruption, anthropologists will almost always employ qualitative methods. To our knowledge, all the empirical research done in economics on corruption has been quantitative. Anthropologists also use diverse methods simultaneously. Staying for a long period of time in a field of research, the anthropologists utilize diverse methods at the same time, including pure observation, participant 
observation, and face-to-face or group interviews. This multiplicity of information collection techniques allows anthropologists to develop a profound knowledge of the observed reality. The proposal to conduct surveys based on multiple methods is also linked to the reality being analyzed. One challenge of inquiry is that corruption remains a hidden practice in most societies. Because corruption is illegal in many countries, it is hard for scientists to approach corruptors. Anthropologists prefer to use several angles of inquiry to understand such a hidden practice. Another challenge is ethnocentrism-the tendency of the observer to analyze from his or her point of view. This is an important bias, especially when investigating an "illegal and immoral" behavior. To combat ethnocentrism, anthropologists try to adopt the point of view of the natives. Ethnographers use such techniques as forming long-term relationships with the field, participating in the natives' activities, comparing, and keeping personal diaries.

When entering a new culture, ethnographers interpret its components. In such circumstances, anthropologists advocate the viewing of corruption as a total social act. A deep analysis of corruption should help illuminate the whole society. For this purpose, anthropology has proposed a holistic perspective of corruption by using multiple points of understanding. As proof of this multifaceted approach, anthropologists prefer to contribute to their field by writing scholarly books, rather than academic articles. The length of a book give them more space to develop different perspectives that contribute to an overall understanding of the society, even if the point of entry is an illegal activity such as corruption.

Analysis of the topic of governance in relation to corruption lends itself well to multiple angles of inquiry. Anthropology has offered three main perspectives on governance that give a rich understanding of the phenomenon: normative, hermeneutic, and transactional. Through a normative analysis, anthropologists have shown that there is a diversity of norms and have therefore criticized simplistic definitions of the state that rely on simplistic dichotomies between public and private. Not only is the state plural, but laws are also as diverse as their reality and perception. Anthropologists do not see the state and the law as instruments in fighting corruption, but rather have shown that they can open opportunities for it. While many scholars in economics and management see regulation as a 
key driver in the fight against corruption, some anthropologists have thought provoking views. Law specifies a sphere of legitimacy, implying what is legal or not. However, the law is decided by the political elite, who could define it for their own interests. Law is therefore not neutral in its aim to define what is good or bad. It is also where the political influence of the elite determines their ability to fix rules for their personal interests. Further, law, law enforcement, and other bureaucratic rules open opportunities for bribing. For example, corrupt bureaucrats might use the complexity of regulation to solicit bribes from uneducated people. From the hermeneutic perspective, public discourses about corruption allow citizens to discuss anxieties and concerns about the social world in general and politics in particular. Following the work of Foucault, anthropological research has shown the importance of analyzing both government and the mentality regarding the exercise of government (i.e. governmentality). To our knowledge, contrary to other social sciences, anthropology has drawn attention not only to the practice of corruption, but also to the need to analyze its discourse. The secretive dialogues about corruption allow the elite to strengthen their power relationships or to eventually gain legitimacy. However, the most interesting point about this approach is that it can analyze corruption through its discourse as well as through its forms and outcomes. A focus on the communicative power of corruption could help shed light on the local understanding of who benefits from corruption and how these benefits are accounted for in society. The analysis of the public discourse about corruption shows how people use corruption in relation to other aspects of their social lives. For example, the discourse could be a time to declare solidarity, cooperation, and struggles among groups. It is also a time for people originally condemning corruption to decide how they could live with it. The latter perspective focuses on the transactions between different social institutions in a dynamic view of corruption. This approach thus concentrates on the negotiation between social actors, especially at the state and local government levels. For example, when the state withdraws from public activities, social actors could take advantage of the absence of local government and either use corruption or the discourse about widespread corruption to promote their personal interests.

\section{Conclusion}


Through its numerous contributions, anthropology offers valuable insights into the understanding of the study of corruption. The field has provided new perspectives particularly in relation to the processual approach, the morality of corruption, methods of inquiry, and governance. Two main lessons can be learned from this field towards a more sound and in-depth understanding of corruption. The first is that corruption cannot be dealt with solely through economic and legalistic approaches, both of which imply a high degree of deductive analysis. These approaches use a macro-theoretical framework to understand a phenomenon that has become famous for its resiliency in time and space. Hence, anthropologists advocate the need to study micro-level processes, actions, and ideas to add a different, and previously neglected, component to the true understanding of the phenomenon.

Second, the holistic approach to the study of corruption may offer a distinct contribution, particularly in the field of business. Anthropological work has proven that approaches focusing on public corruption, or on the political implications of corruption, have to deal with other aspects that are not inextricable, such as forms of social exchange, different moral claims, and private sector transactions. Business ethics can gain important insights from the results of ethnographic investigations that, on the one hand, support the idea that the great diversity in the practices of corruption worldwide is imbued with the particular cultural and social implications of this phenomenon. On the other hand, the holistic approach can suggest ways to interpret these practices that cannot simply be reduced to infringements of the law or anti-market practices, but have their own rationales and produce perceived benefits that are not easily quantifiable in mere economic terms.

To conclude, the anthropology of corruption suggests some crucial topics for further research. First, considering the contributions of anthropology to the subject, this article suggests the need for cross-science research. As Jain (2001) has mentioned, the research on corruption is very fragmented, and researchers show very little understanding of work in academic disciplines outside their field. A key research avenue should be to carry out research programs from different angles at the same time. By using multiple scientific approaches, an interdisciplinary view lends more objectivity to the study and offers new creative ideas leading to better modeling of corruption. 
Second, as mentioned, anthropology stresses the need for a holistic analysis of corruption. This means not only conducting a broader analysis, but also investigating corruption in strict relation with other social factors. The idea of the total social phenomenon is to see in corruption a summary of the functioning of the society under analysis, and to link an element (in our case, corruption) to other social, political, and economic forces. This broader approach to corruption will help us to analyze the interrelationship between diverse social entities such as state, local government, federations of corporations and industries, individual corporations, consulting firms, executives, employees, civil servants, and journalists. For anthropologists, a social phenomenon should be understood when looking simultaneously at diverse "levels" of society, and having a single view (for example, micro at the organizational level) is not sufficient for a complete understanding.

Third, anthropology underlines the need to study the link between culture and corruption. The anthropological tradition stresses that culture is more complex than the usual national stereotypes that can be seen in some social sciences. For example, the idea of a single Chinese culture is foreign to anthropology, which has carried out ample research highlighting the diversity and the transformation of sub- and regional cultures in China. This is obvious considering the country's long history, multiple influences, ethnic components, and demographic size. Thus, anthropologists and other social scientists should analyze the relationship between corruption and culture, sub-cultures, and regional cultures in more detail and complexity. In this line of research, one topic of inquiry could be the discourse of corruption, particularly how different managerial levels in corporations discursively refer to corruption threats in the development of new marketing strategies, expansion, or mergers with foreign companies. Discourse about corruption not only denounces the phenomenon per se, but also expresses concrete needs to acquire information about local practices, or make sense of the political, institutional, and cultural environments in which businesses operate.

Fourth, even though we encourage research from different angles, we particularly feel the need to develop models of corruption at micro levels. Many social sciences look at corruption from a macro level. For example, the analysis of bribery and economic development looks at country level evaluations of corruption and national economic outputs. The ethnographic tradition could be used for an in-depth study of the social 
practices related to corruption. Finally, rather than condemning corruption outright, researchers should try to understand it without adopting a one-sided, judgmental position, thereby enabling them to investigate both the social destruction and the social cohesiveness that corruption can engender. Anthropologists have tried to explain why corruption persists despite negative effects such as lower economic development. Understanding the positive social harmony linked to corruption is also necessary to develop mechanisms to eliminate corruption. Anti-corruption policies developed from a Western point of view fail to investigate the mechanisms that explain the persistence of corruption, and also the "natives" view. In any change program, the necessary changes must be analyzed from the users' perspective. This is also the case for corruption. Thus, we should develop research from a "local" point of view to completely understand corruption. The long tradition of anthropology shows the numerous, potentially stimulating value-added of the natives' views, which can be of great timely relevance in adding a new perspective to the field of business ethics.

\section{References}

Acemoglu, D., Verdier, T. (2000). The Choice between Market Failures and Corruption. American Economic Review, March, 90, 194-211.

Aidt, T. (2009). Corruption, institutions, and economic growth. Oxford Review of Economic Policy, 25, 2, 271-291.

Anderson, C., Tverdova, Y. (2003). Corruption, Political Allegiances, and Attitudes Toward Government in Contemporary Democracies, American Journal of Political Science, vol.47, 1, pp. 91-109.

Atkinson, P., Hammersley, M. (1987). Ethnography. Principles in Practice. London, Tavistock.

Bähre, E. (2005). How to ignore corruption. Reporting the shortcomings of development in Africa. Current Anthropology 46(1): 107-113. 
Bailey, F. (1969). Stratagems and Spoils. New York: Shocken Books.

Banfield, E. (1958). The Moral Basis of a Backward Society. New York: Free Press.

Bardhan, P. (1997). Corruption and development: a review of issues. Journal of Economic Literature, 35: 1329.

Becker, H. (1963). Outsiders: Studies in the Sociology of Deviance. New York: The Free Press, $215 p$.

Bellier, I., Wilson, T. (Ed.) (2000). An Anthropology of the European Union: Building, Imagining and Experiencing the New Europe: Oxford: Berg.

Blundo G., De Sardan O., Bako Arifari N., Tidjani Alou M. (2006). Everyday Corruption and the State: Citizens and Public Officials in Africa. London: Zed Books.

Blundo, G. (2006). Dealing with the local state: the informal privatization of street-level bureaucracies in Senegal. Development and Change 37(4): 799-819.

Blundo, G. (2007). Hidden acts. Open talks. How anthropology can "observe" and describe corruption. In Nuijtel, M. and Anders G. (Ed.) Corruption and the Secret of Law: a Legal Anthropological Perspective. Aldershot: Ashgate, 1-17.

Boas, F. (1887). "Museums of Ethnology and their classification" Science 9: 589.

Boissevain, J. (1974). Friends of Friends: Networks, Manipulators and Coalitions. Oxford: Blackwell. 
Bourgois, P., (1995 / 2003). In Search of Respect: Selling Crack in El Barrio. New York and Cambridge: Cambridge University Press. (Series "Structural Analysis in the Social Sciences".), 432p.

Bourgois, P., Schonberg, J. (2009) Righteous Dopefiend. USA: University of California Press, "Public Anthropology" series. 292p.

Bubandt, N. (2006). Sorcery, corruption and the dangers of democracy in Indonesia. Journal of the Royal Anthropological Institute (New Series) 12: 413-31. 
Cellarius, B. (2002). Environmental non-governmental organizations, civil society and democratization in Bulgaria. East European Politics and Societies 16(1): 182-222.

Clifford, J. and G. E. Marcus (eds), 1986. Writing Culture. The Poetics and Politics of Ethnography. Berkeley: University of California Press.

Corbin, J. (2004). Interés, morality and legality in southern Spain. In Pardo, I (Ed.) Between Morality and the Law. Corruption, Anthropology and Comparative Society. London: Ashgate, 19-32.

Dalakoglou, D. (2010). Migrating-remitting-'building'-dwelling: house-making as 'proxy' presence in postsocialist Albania. Journal of the Royal Anthropological Institute 16: 761-777.

De Sardan, O. (1999). A moral economy of corruption in Africa? The Journal of Modern African Studies 37(1): 25-52.

De Soto, H. (1990). The Other Path: the Invisible Revolution in the Third World. New York, Harper.

De Vries, P. (2007). The orchestration of corruption and excessive enjoyment in western Mexico. In Nuijtel M and Anders G (Ed.) Corruption and the Secret of Law: a Legal Anthropological Perspective. Aldershot: Ashgate, 143-166.

DellaPorta, D. ,Vannucci, A. (1999). Corrupt Exchanges. Actors, Resources, and Mechanisms of Political Corruption. New York: de Gruyter.

DiMaggio, P. and Powell, W. (1983). The iron cage revisited: institutional isomorphism and collective rationality in organizational fields. American Sociological Review, 48(2), 147-160. 
Doig, A., Theobald, R. (Ed.) (2000). Corruption and Democratisation. London, Portland, OR: Frank Cass.

Douglas, M. (1966). Purity and Danger. On the Analysis of the Concepts of Pollution and Taboo. London: Keegan and Paul.

Douglas, M. (1970). Natural Symbols: Explorations in Cosmology. London: Penguin Books.

Douglas, M. (1978). Cultural Bias. London: Royal Anthropological Institute.

Dracklé, D. (2005). Where the jeep comes from: narratives of corruption in the Alentejo (southern Portugal). In Haller D and Shore C (eds.) Corruption: Anthropological Perspectives. London: Pluto, 194-211.

Durkheim, E. (1950). The Rules of Sociological Method, Glencoe, IL: The Free Press.

Evans-Pritchard, E. (1937 / 1963). Witchcraft, Oracles, and Magic Among the Azande. Clarendon Press, 558 p.

Foucault, M. (1991). Governmentality, in G. Burchell, C. Gordon and P. Miller (Ed.). The Foucault Effect: Studies in Governmentality (pp 87-104). Hemel Hempstead: Harvester Wheatsheaf.

Foucault, M. (2007). Security, Territory, Population: Lectures at the Collège de France, 19771978, trans. G. Burchell. Basingstoke and New York: Palgrave Macmillan.

Fukuyama, F. (1995). Trust. The Social Virtues and the Creation of Prosperity. New York: Free Press.

Gambetta,D., Heather, H. (2005). Streetwise. How taxi drivers establish their customers' 
trustworthiness. New York, Sage, 243p.

Geertz, C. (1973). The Interpretation of Cultures: Selected Essays . USA: Basis Books, 470p.

Gledhill, J. (2004). "Corruption as the mirror of the state in Latin America". Pardo, I. (Ed.), 2004. Between Morality and the Law. Corruption, Anthropology and Comparative Society. London: Ashgate, 155-80.

Goldstein, L. (2003). "In our hands": lynching, justice and the law in Bolivia. American Ethnologist: 30(1): 22-43.

Greenwood, R., Oliver, C., Sahlin, K., Suddaby, R. (2008). Organizational Institutionalism. London: Sage, 822p.

Gupta, A. (1995). Blurred boundaries: the discourses of corruption, the culture of politics and the imagined state. American Ethnologist 22(2): 375-402.

Gupta, A., (2005). The discourse of corruption, the culture of politics and the imagined state. American Ethnologist 22(2): 375-402.

Harrison, E. (2010). Unpacking the anti-corruption agenda: dilemmas for anthropologists. Oxford Development Studies 34(1): 15-29.

Hasty, J. (2005). The pleasures of corruption. Desire and discipline in Ghanaian political culture. Cultural Anthropology 20(2): 271-301.

Heidenheimer, A. J. et al. (1989). Political Corruption: A Handbook. New Brunswick, NJ: Transaction Books.

Hoag, C. (2010). The magic of the populace: an ethnography of illegibility in the South Africa immigration bureaucracy. Political and Legal Anthropology Review 33(1): 6-25. 
Holmes, D. (2000). Integral Europe: Fast-Capitalism, Multiculturalism, Neofascism. Princeton: Princeton University Press.

Hsu, C., Smart, A. (2007). Corruption or social capital? Tact and performance of guanxi in market socialist China. In Nuijtel M. and Anders G. (Ed.) Corruption and the Secret of Law: a Legal Anthropological Perspective. Aldershot: Ashgate, 167-90.

Humphrey, C., Sneath, D. (2004). Shanghaied by the bureaucracy. Bribery and post-Soviet officialdom in Russia and Mongolia. In Pardo, I. (Ed.), 2004. Between Morality and the Law. Corruption, Anthropology and Comparative Society. London: Ashgate, 85-100.

Huntington, S. (1968). Political Order in Changing Societies. New Haven: Yale University Press.

Jain, A. (2001). Corruption: a review. Journal of Economic Surveys, 15,1, pp.71-121.

Jain, A. (Ed.) (1998). Economics of Corruption. Dordrecht: Kluwer.

Johnston, M. (2005). Syndromes of Corruption: Wealth, Power, and Democracy. Cambridge: Cambridge University Press.

Kawata, J. (Ed) (2006). Comparing Political Corruption and Clientelism. London, Ashgate.

Kerby, A. (1991). Narrative and the Self. Bloomington, Indiana University Press.

Kondos, A. (1987). The question of "corruption" in Nepal. Mankind , Vol. 17, No. 1, pp. 1529.

Kurer, O. (1993). Clientelism, corruption and the allocation of resources. Public Choice, 77, pp.259-273. 
Lambsdorff, J. (2007). The Institutional Economics of Corruption and Reform. Cambridge: Cambridge University Press.

Lazar, S. (2005). Citizens despite the state: everyday corruption and local politics in En Alto, Bolivia. In D. Haller and C. Shore eds., Corruption: Anthropological Perspectives, London: Pluto Press, pp. 212-228

Leff, N. (1964). Economic development through bureaucratic corruption. American Behavioral Scientist 8(3): 8-14.

Lévi-Strauss, C. (1950/1987). Introduction to the work of Marcel Mauss. London : Routledge,89p.

Lévi-Strauss, C. (1955 / 1973) Tristes Tropiques English translation by John and Doreen Weightman) New York: Atheneum.

Lévi-Strauss, C. (1958 / 1963). Structural Anthropology. USA: Basic Books, 411p.

Levine, A. (2004). The transparent case of virtuality. PoLar 27(1): 9-113.

Leys, C. (1965). What is the problem about corruption? Journal of Modern African Studies, 3(2), 215-230,

Lomnitz, L. (1995). Ritual, rumor and corruption in the constitution of polity in modern Mexico. Journal of Latin American Anthropology 1(1): 20-47.

Lovett, S., Simmons, L., Kali, R. (1999). Guanxi versus the Market: Ethics and Efficiency. Journal of International Business Studies, 30, 2: 231-247;

Lui, F. T. (1985). An equilibrium queuing model of bribery. Journal of Political Economy, 
93(4), 760-781.

MacNaughton E., Wong K. (2007). Corruption judgements in pre-war Japan: locating the influence of tradition, morality and trust on criminal justice. In Nuijtel M. and Anders G. (Ed.) Corruption and the Secret of Law: a Legal Anthropological Perspective. Aldershot: Ashgate, 77-98.

Malinowski, B. (1922 / 1984). Argonauts of the Western Pacific: An account of native enterprise and adventure in the Archipelagoes of Melanesian New Guinea. USA: Waveland Press, 527p.

Mauro, P. (1995). Corruption and growth. Quarterly Journal of Economics, 110(3), 681-712.

Mauss, M. (1923/2005). The gift: the form and reason for exchange in archaic societies. Milton Park: Routledge (classics), 201p.

Mead, M. (1928 / 2001). Coming of Age in Samoa. A psychological study of Primitive Youth for Western Civilization. USA: New York, HarperCollins, Perennial Classic, 228p.

Meloni, B. (Ed.). (1997). Famiglia meridionale senza familismo. Strategie economiche, reti di relazione e parentela. Catanzaro: Meridiana.

Miller, A (2004). Corruption between morality and legitimacy in the context of globalization. In Pardo I. (Ed.) Between Morality and the Law. Corruption, Anthropology and Comparative Society. London: Ashgate, 53-68.

Miller, R. (1974). Are familists amoral? A test of Banfield's amoral familism hypothesis in a south Italian village. American Ethnologist 1(3): 515-35. 
Misangyi, W., Weaver, G., Elms, H. (2008). Ending corruption: the interplay among institutional logics, resources, and institutional entrepreneur. Academy of Management Review, 33,3, pp.750-770.

Montinola, G., Jackman, R. (2002). Sources of Corruption: A Cross-National Study," British Journal of Political Science 32:147-170.

Moore, S. (2000). Law as Social Process. Hamburg: LIT.

Morris, S. (1991). Corruption and politics in contemporary Mexico, Tuscaloosa, AL: University of Alabama Press.

Muraskin, W. (1974). Review: the moral basis of a backward sociologist. Edward Banfield, the Italians and the Italian-Americans. American Journal of Sociology 79(6): 1484-96.

Myrdal, G. (1968). Asian Drama: An enquiry into poverty of nations, vol. 2, New York: The Twentieth Century Fund. Reprint in A. Heidenheimer, M. Johnston, and V. LeVine (Ed.) Political Corruption, pp. 953-961, 1989. Oxford: Transaction Books.

North, D. (1990). Institutions, Institutional Change and Economic Performance. Cambridge: Cambridge University Press.

North, D. (1991). “Institutions”. Journal of Economic Perspectives 5(1): 97-112.

Nuijten, M. Anders, G. (2007) (Ed.) Corruption and the Secret of Law: a Legal Anthropological Perspective. Aldershot: Ashgate.

Nye, (1967). "Corruption and political development: A cost-benefit analysis". The American Political Science Review, 61 (2), 417-427.

Olson, M. (1971). The Logic of Collective Actions. Public Goods and the Theory of the Groups. 
New York, Schocken Books.

Pardo, I. (Ed.)(2004). Between Morality and the Law. Corruption, Anthropology and Comparative Society. London: Ashgate.

Parry, J. (2000). The crisis of corruption and the idea of India-a worm's eye view. In I. Pardo (Ed.) Morals of Legitimacy: Between Agency and System. Oxford: Bergahn Books, 27-56.

Parsons, T. (1968 [1937]). The Structure of Social Action. A Study in Social Theory with Special Reference to a Group of Recent European Writers, New York, London: Free Press.

Pelto, P., Pelto, G. (1970/1996). Anthropological Research: the structure of inquiry. Cambridge University Press, 352 p.

Plattner, S. (1989). Economic Anthropology. Stanford: Stanford University Press, 487p.

Prato, G. (2004). The devil is not as wicked as people believe, neither is the Albanian. Corruption between moral discourses and national identity. In Pardo, I. (Ed.), 2004. Between Morality and the Law. Corruption, Anthropology and Comparative Society. London: Ashgate, 69-84.

Price, P. (1999). Cosmologies and Corruption in (South) India. Forum for Development Studies, No. 2, 315-327.

Punch, L. (1986). The social construction of police deviance and control. London: Tavistock pub. 249 p.

Putnam, R. (1993) Making Democracy Work. Civic Traditions in Modern Italy. Princeton: Princeton University Press.

Putnam, R., (2000) Bowling Alone. The Collapse and Revival of American Community. New 
York: Simon and Schuster.

Radcliffe-Brown, A. (1952 / 1965). Structure and Function in Primitive Society: Essays and Addresses. USA : New York, First Free Press.

Rigi, J. (2004). Corruption in post-Soviet Kazhakstan. "In Pardo, I. (Ed.), 2004. Between Morality and the Law. Corruption, Anthropology and Comparative Society. London: Ashgate, 101-118.

Rivkin-Fish, M. (2005). Bribes, gifts and unofficial payments: re-thinking corruption in postSoviet health care. In D. Haller and C. Shore (Ed.) Corruption. Anthropological Perspectives. London: Pluto Press, 47-64.

Rodrik, D., Subramanian, A. (2003). "The Primacy of Institutions." Finance and Development (June): 31-34.

Rose-Ackerman, S. (1999). Corruption and Government. Causes, Consequences, and Reform. Cambridge, New York: Cambridge University Press.

Rose-Ackerman S (Ed.) (2006). International Handbook on the Economics of Corruption. Cheltenham: Edward Elgar.

Rothstein, B., Eek, D. (2009). Political corruption and social trust. An experimental approach. Rationality and Society 21(1): 81-112.

Rudnyckyj, D. (2009). Spiritual economies: Islam and neoliberalism in contemporary Indonesia. Cultural Anthropology 24(1): 104-141.

Ruud, A. (2000). Corruption as everyday practice. The public-private divide in local Indian society. Forum for Development Studies 2: 271-94. 
Ruud, A. (2001). Talking dirty about politics. A view from a Bengali village. In C.J. Fuller and V. Benei (Ed.) The Everyday State and Society in Modern India. London: C.Hurst and co., 115-36.

Schneider, J., Schneider, P. (2005). The sack of two cities: organized crime and political corruption in Youngstown and Palermo. In Haller D and Shore C (Ed.) Corruption: Anthropological Perspectives. London: Pluto, 29-46.

Scott, J. (1972). Comparative Political Corruption. Englewood Cliffs, NJ: Prentice Hall.

Scott, S. (2010). Negotiating power: elections and the constitution of indigenous Taiwan. American Ethnologist 37(4): 726-740.

Sedlenieks, K. (2004). Rotten talk: corruption as a part of discourse in contemporary Latvia. In Pardo, I (Ed.) Between Morality and the Law. Corruption, Anthropology and Comparative Society. London: Ashgate, 119-134.

Sewanta, K. (2009). Local level perception of corruption: an anthropological inquiry. Dhaulagiri Journal of Sociology and Anthropology 3: 163-74.

Sharma, A., Gupta, A. (Ed.)(2006). The Anthropology of the State: a Reader. Maldern: Blackwell.

Shibutani, T. (1986). Social Processes. Bekerley, University of California Press, 579p.

Shleifer, A., Vishny, R. (1993). “Corruption.” Quarterly Journal of Economics, August, 108 (3), 599-617.

Shore, C. (2005). Culture and corruption in the EU: reflections on fraud, nepotism and cronyism in the European Commission. In D. Haller and C. Shore (Ed.) Corruption. Anthropological Perspectives. London: Pluto Press, 131-55. 
Shore, C., Wright, S. (Ed.)(1997). Anthropology of Policy. Critical Perspectives on Governance and Power. London: Routledge.

Silverman, S. (1968). Agricultural organization, social structure and values in Italy: amoral familism reconsidered. American Anthropologist 70(1): 1-20.

Smart, A., Hsu C. (2007). Corruption or social capital? Tact and the performance of guanxi in market socialist China. In Nuijtel M. and Anders G. (Ed.) Corruption and the Secret of Law: a Legal Anthropological Perspective. Aldershot: Ashgate, 167-190.

Steward, J. (1955 / 1990). Theory of Culture Change: The Methodology of Multilinear Evolution. University of Illinois Press.

Sumner, W. (1906). Folkways: A study of the sociological importance of usages, manners, customs, mores, and morals. Boston, Ginn, 692p.

Sun, Y. (2004). Corruption and Market in Contemporary China. Cornell University Press.

Svenson, J. (1995). "Eight Questions about corruption". Journal of Economic Perspectives, vol.19, 3, pp.19-42.

Tanzi, V. (1998). Corruption Around the World. Causes, Consequences, Scope and Cures. International Monetary Fund Staff Papers, December, 45 (4), 559-594.

Tarrow, S. (1996). Make social science work across space and time: a critical reflection on Robert Putnam's Making Democracy Work. American Political Science Review, 90(2): 389-97.

Torsello, D. (2010). Corruption and the economic crisis: empirical indications from Eastern Europe. Slovak Foreign Policy Affairs. 19(2): 65-75.

Torsello, D. (2012). The New Environmentalism? Civil Society and Corruption in the Enlarged 
EU. Farnham, UK: Ashgate.

Turner, S. (2007). Corruption narratives and the power of concealment: the case of Burundi's civil war. In Nuijtel, M. and Anders, G. (Ed.) Corruption and the Secret of Law: a Legal Anthropological Perspective. Aldershot: Ashgate, 125-142.

Tylor, E. (1871/1920). Primitive Culture. Origins of culture. London: Murray ed., (vol. 1), $454 p$.

Varese, F. (2005). The Russian Mafia Private Protection in a New Market Economy. Oxford University Press.

Venard, B., Hanafi, M. (2008). Organizational isomorphism and corruption in financial institutions: An empirical research in emerging countries. Journal of Business Ethics, 81: 481498.

Venard, B. (2009). Organizational isomorphism and corruption: An empirical research in Russia. Journal of Business Ethics, 89: 59-76.

Venard, B. (2009). Corruption in firms in emerging countries. A matter of isomorphism. M@n@gement 12 (1): 1-27.

Visvanhatan, S. (2008) The necessity of corruption. http://www.india seminar.com/2008/590/590_shiv_visvanathan.htm, accessed 3-10-2010.

Wade, R. (1982). The system of administrative and political corruption: Canal irrigation in South India. The Journal of Development Studies, Vol.18, No. 3, pp. 287-327.

Weber, M. (1922/1978). Economy and Society; An outline of interpretive sociology. Berkeley, University of California Press. 
White, L. (1959). The Evolution of Culture: The Development of Civilization to the Fall of Rome. New York, McGraw-Hill. 272 p.

Wolcott, (1995 / 2005). The art of fieldwork. USA : Rowman Alta Mira Press. 292p.

World Bank (2006). World Bank Literature Survey on Corruption; 2000-2005, 28 March 2006, http://www1.worldbank.org/publicsector/anticorrupt/ACLitSurvey.pdf (accessed 1-102010).

World Bank, (1997). Helping countries combat corruption. Poverty Reduction and Economic Management Unit, Report, June.

Xin, K. Pearce, J., (1996). Guanxi, Connections as substitute for formal institutional support. Academy of Management Journal. 39, 6, pp.1641-1658.

Yang, M. (1994). Gifts, Favors and Banquets: The Art of Social Relationships in China. Ithaca: Cornell University Press.

Yang, M. (2002). The resilience of Guanxi and its new deployments: a critique of some new Guanxi scholarship. China Quarterly 170: 459-76.

Zerilli, F. (2005). Corruption, property restitution and Romanianness. In Haller D and Shore C (Ed.) Corruption: Anthropological Perspectives. London: Pluto, 83-102.

Zinn, D. (2001). La raccomandazione: clientelismo vecchio e nuovo. Roma, Donzelli.

Znoj, H. (2007). Deep corruption in Indonesia: discourses, practices, histories. In Nuijtel M and Anders G (Ed.). Corruption and the Secret of Law: a Legal Anthropological Perspective. Aldershot: Ashgate, 53-76. 